\title{
LECTURA PERFORMATIVA DUNHA IMAXE DE ESTÍBALIZ ESPINOSA LACTANTE
}

Data de recepción: 05.11.2020

Data de aceptación: 13.04 .2021

Resumo: O deslocamento do texto da centralidade do drama deixa o campo aberto á posteatralidade e, igualmente, abre un camiño para a realización doutras accións como o happening e a performance, onde o corpo e a audiencia pasan a ser protagonistas, confundíndose, en ocasións, vida e obra. As Redes Sociais Dixitais constitúen un novo espazo de expansión e proxección que está a ser empregado por mulleres artistas e poetas para desenvolver a súa expresión creativa. Estes territorios virtuais son utilizados por elas, asemade, como ferramenta de de-construción da sociedade patriarcal e como instrumento de subversión e transgresión. Por tanto, moitas das intervencións que realizan nestes contornos teñen un forte compoñente de activismo político e social, establecendo unha continuidade entre as esferas pública e privada; convértense así en espazos para a (re)presentación. Dentro destas accións están aquelas que teñen como obxectivo desmontar as construcións patriarcais e os tabús arredor do corpo da muller, como a campaña \#brelfie. Neste contexto, analizamos unha acción lactivista transmedia realizada por Estíbaliz Espinosa, poeta e artista multifacetada galega e establecemos liñas de fuga que nos conducen a todo un universo de imaxes lactantes da historia da arte até a contemporaneidade.

Palabras chave: Estíbaliz Espinosa, performance, Redes Sociais Dixitais, lactivismo, posteatralidade

Title: Performative Reading of Estíbaliz Espinosa's Image Breastfeeding

\begin{abstract}
The displacement of text from the center of theatrical works creates the space for the emergence of postdramatic theatre and also makes possible other interventions such as happenings and performance, in which the body and the audience become protagonists, sometimes blurring the line between life and art. Digital Social Networks constitute a new space used by female artists and poets to expand, project, and develop their creative expression. They also use these virtual territories as a tool to deconstruct patriarchal society and as an instrument of subversion and transgression. Therefore, many of the interventions they carry out in these settings have a strong component of political and social activism, establishing continuity between the public and private spheres; they thus become spaces for (re)presentation. Included in these interventions are those that aim to dismantle patriarchal constructions of women's bodies, such as the \#brelfie campaign. In this context, we analyze a transmedia lactivist action performed by Estíbaliz Espinosa, a Galician poet and multidisciplinary artist, and we establish outward connections to a world of both historical and contemporary artistic images of breastfeeding.
\end{abstract}

Keywords: Estíbaliz Espinosa, performance, Digital Social Networks, breastfeeding, postdramatic theatre 


\title{
DA TEATRALIDADE Á POSTEATRALIDADE E PERFORMATIVIDADE NAS PLATAFORMAS SOCIAIS VIRTUAIS
}

\begin{abstract}
Theater-minus-text, it is a density of signs and sensations built up on stage starting from the written argument; it is that ecumenical perception of sensuous artifice - gesture, tone, distance, substance, light - which submerges the text beneath the profusion of its external language.
\end{abstract}

(Barthes 1972: 26)

Roland Barthes, no seu ensaio sobre Baudelaire, define a teatralidade como un teatro sen texto, "un espesor de signos" onde o drama é construído na escena, co corpo, os xestos e as emocións, unha linguaxe exterior que despraza o cerne do logocentrismo hacia á performance (2003:54). No mesmo sentido, Juan Villegas equipara o teatro a calquera escena vital individual ou colectiva que se realice na presenza dunha audiencia: "Parto del supuesto que toda actividad social constituye un comportamiento teatral, en el cual los individuos y las instituciones se comportan como actores en el escenario social" (1999: 25).

Esta ruptura do paradigma textocentrista intensifícase coa aparición da $w w w$, un mundo virtual policéntrico potenciado nas Redes Sociais Dixitais ${ }^{1}$, que pasarán a ser a escena virtual para calquera tipo de acción performativa. Estamos nese mundo móbil e caótico, ordenado polo azar, ao que se refire Abuín González (2006), en que o textual dá paso a outras formas de narratividade, que se basean precisamente, nesa ausencia de texto e de orde, así como no dominio do hipermedia, como é o caso do teatro posdramático e a performance.

Os actos performativos comezaron nos anos previos á I Gran Guerra, nas vangardas artísticas, en Italia co movemento futurista ou en Suiza con accións artísticas dos dadaístas do Cabaret Voltaire e, especialmente, co "teatro da crueldade" de Artaud. Retomaríanse nos anos 60 e 70 con Allan Kaprow, considerado como o creador do que hoxe coñecemos como happening, manifestación artística intimamente relacionada coa performance. Protagonistas de arte-acción serán, entre outros, John Cage, Joseph Beuys, Yoko Ono, os compoñentes do grupo Fluxus, Carolee Schneemann, Marina Abramović ou artistas do accionismo vienés como Otto Muehl. Nestes casos o texto deixa de existir. A representación fuxe da escena teatral, artistas visuais e poetas transfórmanse en actores que ofrecen unha creación transmedia (plástica, visual, sonora e corporal) a unha audiencia que descoñece o contido do evento ao que van asistir. Happenings e performance son accións efémeras que procuran a participación do público. No primeiro caso son impro-

\footnotetext{
1 Utilizaremos o acrónimo RSD para referirnos ás redes sociais dixitais (plataformas como Facebook, Twitter, Instagram ou Youtube, entre outras). Son plataformas de comunicación sociais dixitais, compostas por grupos de persoas con intereses comúns onde estas se reúnen, comunican e comparten información de forma virtual, a través de internet. Destacan actualmente: Facebook, Twitter ou Instagram.
} 
visadas e inmediatas, poden acontecer en calquera lugar e momento e despois desaparecen. Hoxe esa característica do instantáneo dilátase, as accións son fotografadas ou filmadas, e retransmitidas nas RSD e a participación do público continúa na (re)presentación e multiplicación das mesmas.

O corpo é protagonista na performance, concentra a expresión, o movemento, a voz, a tensión emocional, en moitas ocasións, incluso, a violencia. Pode ser utilizado como instrumento de subversión. Neste sentido está todo o pensamento corporal de Artaud. Para o autor o teatro é o mecanismo que nos (re)comunica coa vida e, ao mesmo tempo, unha vía para renunciar ao propio teatro (como a toda obra literaria ou artística). Artaud (1938) defende un teatro-acción transgresor da orde establecida na linguaxe e na arte, e crea o "teatro da crueldade", centrado na vida mesma, elemento redentor para unha cultura occidental contaminada por unha linguaxe núa, baleira, desposuída e separada do corpo.

A transposición do teatro alén do texto leva ao que Hans-Thies Lehmann (1999) denominou teatro posdramático que se caracteriza por esa des-centralización do texto na obra, o afastamento da mímese aristotélica, e por unha de-construción de todos os factores que interveñen nunha representación: personaxes, tempo, espazo e autoría.

Unha vez despoxada a teatralidade do texto, ou eliminada a centralidade deste, focaremos a atención, non xa no autor/a, senón na audiencia, na mirada do outro. Cornago nos seus estudos sobre teatralidade indica que, independentemente da consideración de teatralidade como algo exclusivo da escena, ou estendido a calquera acción social, a sociedade de consumo e a revolución dos medios de comunicación aumenta os niveis de teatralidade a través da multiplicación dos espazos. Expresa que o teatro "es el único medio que, al carecer de lenguaje exclusivo y propio, ha de tomar sus códigos de aquellos que ofrece la cultura en la que se desarrolla" (Cornago 2009: 2). O propio autor establece unha serie de factores para que exista teatralidade nunha acción, entre os que toma especial protagonismo a mirada do outro, a necesidade da existencia dun espectador ou espectadora. Un segundo factor a ter en conta é que debe ser algo "procesual", que só ten realidade cando está a funcionar; o terceiro é que se trate dunha representación e que esta sexa visible. Non todas as representacións teñen teatralidade, para que a esta exista nunha representación debe existir unha "ollada oblicua", aquela que observa tanto a representación como o proceso que fai que esta exista. Conclúe así nunha teatralidade como paradigma estético da modernidade, nesa consciencia individual e colectiva da realidade como representación.

Esa mirada é constante nas RSD, non podemos afastarnos da ollada do outro, sempre presente en cada acto da nosa vida. Precisamos vernos na mirada do outro para ser, existir. Rettberg (2017) analiza as diferenzas entre presentación e representación nas plataformas virtuais das redes sociais, onde a representación sería o equivalente á mímese aristotélica e a presentación correspondería cunha acción, con aquilo que a persoa fai para presentarse de seu. No entanto, en moitas ocasións, nas RSD aquilo que se presenta pode ser, igualmente representado, unha mímese de algo previamente ensaiado e non unha produción espontánea. Podemos enlazar esta última idea coa denominada por Guy Debord (1967) como "sociedade do espectáculo", sendo o espectáculo unha relación social entre persoas mediada por imaxes, e que Paula Sibilia (2008) aplica ao mundo do ciberespazo e pasa a designar "intimidade como espectáculo" ou extimidade, retomando o concepto 
de Jacques Lacan e Jacques-Allain Miller (2006). Situámonos no fin dos límites entre arte e vida previamente anunciados por Antonin Artaud e John Cage.

As redes sociais en liña forman parte da nosa vida diaria e, actualmente, son un dos medios principais cos que nos relacionamos coa sociedade. Permítennos crear información e inter-accionar cun público cada vez maior que, no caso das celebridades, está expectante ante cada nova publicación. A través delas podemos incluso chegar a influír noutras persoas e modificar comportamentos. O tempo virtual confúndese co tempo de vida, a vida é substituída, en ocasións pola ficción, e a ficción pasa a representar a vida. A vida diaria pasa a ser unha representación teatral e incluso unha performance, un produto preparado e teatralizado, onde proxectamos a nosa identidade ante unha audiencia (sociedade) que poder chegar a ser influída por nós (Goffman 1959). No ciberespazo o auditorio son todas as persoas internautas que asisten a todas a nosas representacións de vida ficcionada.

As RSD son espazos performativos, parte dos non lugares de Marc Augé (1992), lugares en movemento, en continua transformación nos que a persoa se presenta e representa nunha performance da súa personalidade (Fernández Navazas 2011). Nestes ciberespazos o público agóchase tras os seus computadores e dispositivo móbeis, onde, simultaneamente, realizan accións "cibernéticas" que establecen unha comunicación coa acción principal. Son a un tempo persoas co-creadoras de accións e de contido e un público que medra de forma exponencial, entra no espazo e se integra no discurso. Nas RSD convertémonos en prosumidores. O non lugar de Augé transfórmase nun non lugar común, un espazo público no que, en moitas ocasións, quen realiza a acción pretende intervir e influír sobre a persoa expectante. Igualmente, podemos relacionar estas plataformas co terceiro lugar ou o entre-lugar descrito por Homi Bhabha (1994), un espazo intermedio para conformarmos novas subxectividades e, asemade, un sitio de hibridación entre o público e o privado e, igualmente, vida e ficción.

As (re)presentacións nas RSD son posdramáticas, non son logocentristas, a centralidade está agora na acción, na inter-relación entre o eu que actúa e a sociedade que observa e experimenta. Poderiamos falar dunha sintaxe das imaxes para a construción dun discurso teatral nun perfil de Facebook ou Instagram. Esa acción utiliza a imaxe como símbolo, a fotografía pasa a ser a linguaxe. Vivimos no tempo da pos-fotografía, onde as imaxes se transforman nun "acto" de comunicación e de linguaxe (Foncuberta 2016). A través fundamentalmente da fotografía presentámonos como "eus espaciais", imaxes coidadas de nós que se converten en auto-presentacións (Schwartz e Halegoua 2015). Para esas auto-presentación podemos utilizar selfies mais tamén imaxes que outras persoas realizan de nós nas que retratan as nosas experiencias de vida. Estas imaxes, antes da irrupción das redes sociais, pertencían ao mundo privado para ser unicamente compartidas coa familia ou amizades máis próximas (Bourdieu 1965, Rettberg 2017). En plataformas como Facebook, Instagram ou Twitter é difícil manter unha separación entre os diferentes grupos cos que temos conexión e a esfera pública invade a esfera privada e viceversa. Esa irrupción pode ser procurada para unha finalidade concreta. Sinalaba Arendt (2001) que a esfera privada era un espazo de protección e ao mesmo tempo de falta de liberdade, onde vai ficar todo o que se desexa permaneza oculto. Era, por esa razón, o espazo das mulleres e, con elas, do seu corpo só creado para desfrute do home en privado. Ese 
espazo estivo sempre reservado a nai e á súa relación con fillos, ao alimento, ao aleitamento no calor da intimidade do cuarto.

Os espazos públicos das plataformas virtuais convértense en espazos libres para realizarmos accións sociais e políticas que reivindican un espazo propio. Son para as mulleres "cuartos propios conectados" onde xestionar a súa privacidade (Zafra 2010: 23-24). Transfórmanse en ocasións en lugares para unha performance subversiva, seguindo a idea de Butler (2007), cunha intención clara de desmontar o discurso falocéntrico. Son espazos propicios para actuar á inversa, non aceptar a norma histórico-patriarcal e asemade, espazos de visibilidade daquilo que transgride dita norma (Pérez e Sotelo 2013).

O ciberespazo é tamén un lugar de tensión entre o individual e o colectivo, (re)presentarmos ante a colectividade mais tamén dentro dela, o que no caso das identidades subalternas dá lugar a unha forte sororidade ou pacto de xénero (Lagarde 2009), como analizaremos a seguir no caso concreto dos brelfies.

\section{DE-CONSTRZUÍR O DISCURSO FALOCÉNTRICO ARREDOR DA MATERNIDADE: $\mathrm{O}$ \#BRELFIE}

O estudo anual de redes sociais que realiza о гав Spain indica que un $87 \%$ das persoas internautas en España utilizan algunha plataforma de redes socias e aproximadamente mil millóns de persoas en todo o mundo utilizan Instagram (2020). Instagram, a diferencia de Facebook ou Twitter creadas para introducir texto, nace como unha plataforma na que a imaxe é a protagonista, algo que hoxe comeza a invadir tamén as outras plataformas mencionadas. As imaxes van acompañadas en ocasións dun texto breve e adoitan levar hashtags ou etiquetas co aspecto que se desexa resaltar. Así unha imaxe é signo e significado a un tempo, pode presentar a unha persoa, influír en quen a observa e provocar diferentes reaccións.

Como xa comentamos, as plataformas sociais aumentan os espazos nos que insistir sobre cuestións identitarias e de xénero, sendo lugares idóneos para actos performativos que incidan no empoderamento da muller. Do $85 \%$ citado antes, o 51\% son mulleres e no caso de Instagram esa porcentaxe aumenta $75 \%$. Se ben son abundantes os selfie que lexitiman unha feminidade tradicional enquistada na sociedade patriarcal, tamén son datos indicativos da necesidade dun espazo de visibilidade no que se presentaren, de posta en común de aspectos identitarios e de unión e sororidade para desmontaren ese discurso falocéntrico. Nesta liña contamos con numerosos estudos nos que se analiza o selfie como expresión creativa de empoderamento da muller (Pham 2015; Gill 2016; Schmeichel, Kerr e Linder 2017). Centrarémonos neste aspecto para analizar o debate xurdido arredor dos selfie, publicados nas redes sociais en liña, de mulleres lactantes, moitas delas procedentes do mundo do espectáculo, e como esas imaxes se transforman en accións performativas cunha intención non só de presentación, senón tamén de modificar os compor-

2 O hashtag \#brelfie fórmase a partir do termo breastfeeding (aleitamento materno) e selfie (autorretrato realizado cun smartphone). 
tamentos patriarcais, para se inseriren dentro dunha cultura de influíntes. Ese modelo de se presentaren pode ofrecer unha lectura en clave autobiográfica, creada en moitas ocasións case exclusivamente a base de imaxes. Neste contexto realizaremos a posteriori unha reflexión sobre dúas imaxes publicadas nestes medios por Estíbaliz Espinosa ${ }^{3}$, na que a poeta se (re)presenta aleitando o seu fillo nun espazo público.

O debate sobre a lactación materna en espazos públicos intensificouse nas plataformas virtuais de redes sociais a raíz de que a actriz Alyssa Milano publicara en Instagram (27 de outubro de 2014) un selfie aleitando á súa filla (Fig. 1). Foi o inicio da campaña que utilizaba o hashtag \#brelfie para reivindicar a lactación materna en espazos públicos, algo que a día de hoxe aínda continúa a ser cuestionado, incluso pode levar algún tipo de sanción. O brelfie de Alyssa foi seguido por outras celebridades como Liv Tyler, Sara Carbonero ou Mila Kunis e actualmente hai en Instagram máis de 89.000 publicacións co hashtag \#brelfie.
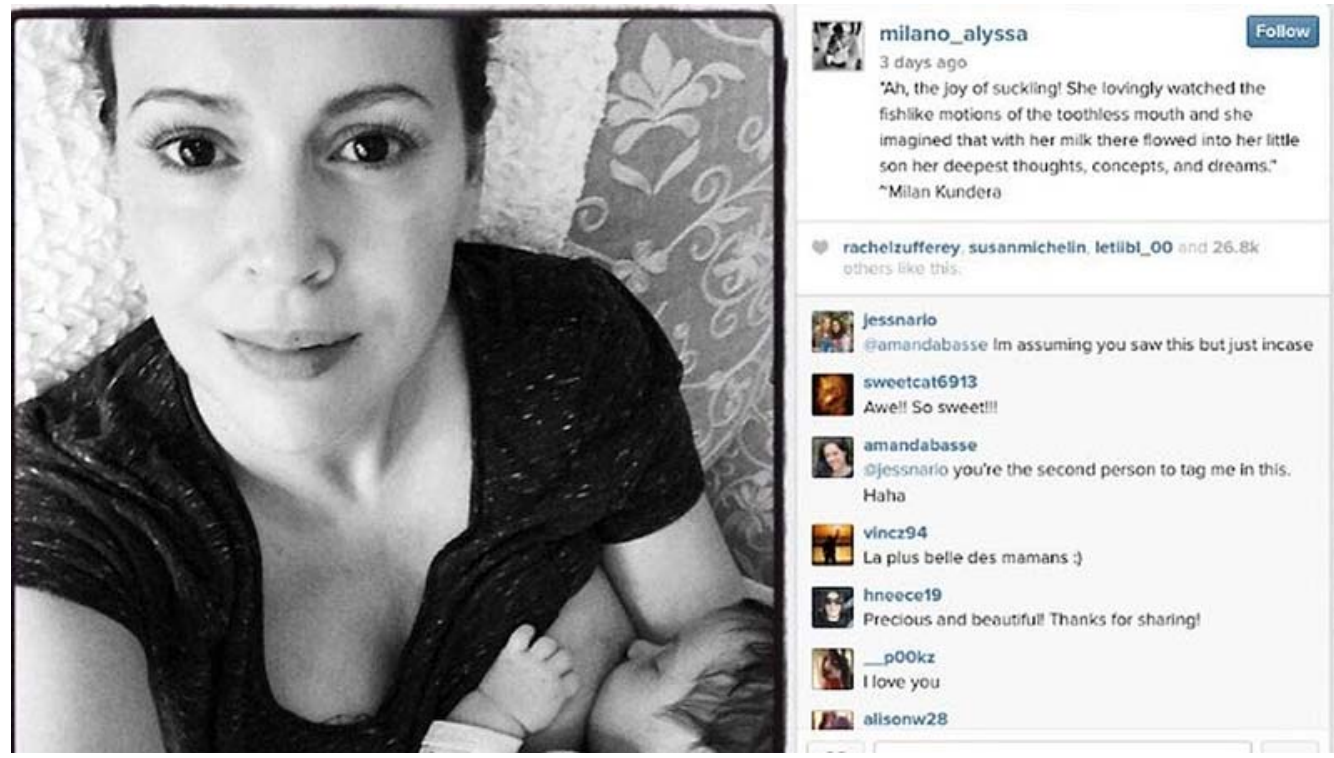

Fig. 1 Publicación en Instagram de Alyssa Milano (27 de outubro de 2014).

Este tipo de acción tenta desmontar as construcións patriarcais e os tabús arredor do corpo da muller, da maternidade e da lactación pública tantas veces cuestionada para transformala nunha expresión de activismo social e político (Buller 2016). Nesta liña temos tamén o traballo fotográfico de artistas como Ashlee Wells Jackson co seu proxecto

\footnotetext{
3 Estíbaliz Espinosa (1974-) é autora multidisciplinar: poeta, crítica literaria e musical, investigadora, tradutora, conferenciante e cantante de ópera e jazz. Licenciada en Socioloxía e en Filoloxía Hispánica Preséntase a si mesma como "criatura híbrida e cyborg" na súa web https://estibalizespinosa.com. Alén da súa faceta como creadora, como afeccionada á ciencia, especialmente á astronomía, ten un importante papel na súa divulgación, especialmente da obra de mulleres científicas. Utilizaremos eE para referirnos a esta autora.
} 
Bodies Project: Celebrating the Uncensored Beauty of Motherhood (2015) ou o de Stacie Turner Breastfeeding In Real Life, difundido no diario Huffington Post (2013).

Dentro dos estudos de xénero existen diferentes actitudes con respecto á lactación materna ${ }^{4}$ : posicionamentos lactivistas que a eloxian e promoven, considerándoa como empoderamento da muller; así sería o caso do feminismo francés do XIX ou actualmente do eco-feminismo que fomenta a lactación pública como práctica subversiva, de-colonial e anti-capitalista, igualmente como movemento de resistencia ante os poderes económicos (Massó Guijarro 2013); ou, pola contra, teorías que a ligan ao neoliberalismo patriarcal, ao relegar á nai a unha función reprodutora e coidadora, limitando así a súa liberdade. Esta última era a visión de Simone de Beauvoir, Kate Millet ou do feminismo radical de Shulamith Firestone na segunda metade do xx.

Ester Massó Guijarro, unha das principais promotoras do lactivismo en España, define este como "activismo por la lactancia materna" e indica que se debe circunscribir a un contexto cultural occidental e de contornas de clase media (2015b: 194-195). A mesma autora insiste no dereito a un aleitamento libre e sen censura: "El lactivismo es apoyar la lactancia materna libre, como derecho fundamental de toda persona de amamantar y ser amamantado. Sin tener que esconderse $-\mathrm{y}$ sin que las fotografías de este acto puedan ser censuradas-" (183).

No entanto, si podemos referir que existen experiencias diversas ao abeiro de variábeis como a etnia, idade, clase ou preferencia sexual (cf. Braidotti 2004, Rábade Villar 2018). As nais negras e afrodescendentes arrastran séculos de represión lactivista, de tempos de escravitude onde aleitar era unha opción só para as persoas "brancas". Actualmente existen movementos que promoven o aleitamento das mulleres negras, como as Chocolate Milk Mommies, creadoras en 2014 da Black Breastfeeding Week. Elas publican as súas imaxes nas redes sociais con hashtags como \#blackbreastfeeding, \#blackbreastfeedingisbeatiful, \#blackqueens ou \#normalizedbreastfeeding. As fotografías (Figs. 2 e 3) revelan un empoderamento feminino a través da lactación, que presentan como un símbolo de forza tanto do corpo feminino como da transmisión, a través do leite, da súa etnia. Nestas imaxes a muller encárase co público nunha actitude de toma de poder, en claro contraste coa fotografía tirada a principios do século xx en Adana (Turquía) (Fig. 4) onde unha muller negra, seguramente ama de crianza, aleita un bebé branco e posa, sen desafiar á cámara, nunha escena que recrea un espazo privado.

\footnotetext{
4 O panorama internacional das diferentes posicións arredor do lactivismo son moito máis extensas, porén, non é o obxecto do noso estudo afondar nelas, unicamente deixar constancia das teorías principais e constatar esa diversidade a través dalgúns exemplos. Interésanos trazar un marco onde podermos situar a EE e a súa intervención.

5 Trátase dunha fotografía de estudo impresa nunha postal da época, onde indica un nome, G. Mizrahi, e un lugar, Adana. Consérvase no Museum of Fine Arts de Boston, onde indica a data aproximada (ca. 1900). Non coñecemos máis información sobre a súa autoría. https://collections.mfa.org/objects/574888 [15.04.2021].
} 


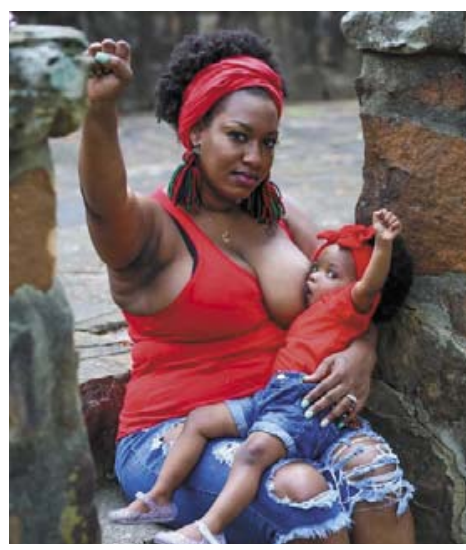

Fig. 2 Publicación en Instagram de Chocolatemilkmommies (22 de marzo de 2021).

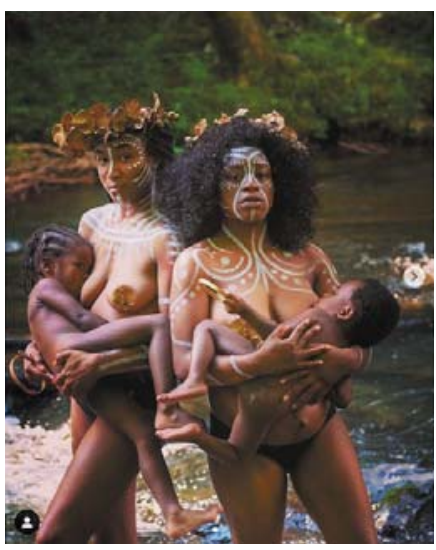

Fig. 3 Publicación en Instagram de Lakisha Cohill (13 de agosto de 2018).

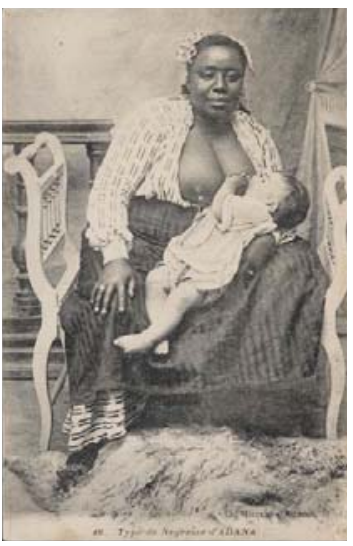

Fig. 4 G. Mizrahi, Type de negresse d'Adana (ca.1910).

O aleitamento nos espazos públicos, comezou a ser rexeitado, a mediados do século $\mathrm{xx}$, por unha parte da sociedade occidental, aquela de procedencia maioritariamente burguesa, quedando relegado ao campo doméstico. A erotización do peito feminino implicou que hoxe se considere obscena ou pornográfica a lactación en público, sendo censurada, en ocasións, nas redes sociais en liña, como aconteceu coa eliminación entre 2012 e 2013, por parte de Facebook, de varias imaxes de mulleres por amosaren o peito nu ao aleitaren os fillos. Esta política xerou numerosas críticas e denuncias, polo que actualmente existe unha aclaración, tanto en Facebook como en Instagram ${ }^{6}$ na que indica que si están permitidos as imaxes de lactación materna. Todo isto resulta anacrónico, máis de termos en conta todas as imaxes de virxes que aleitan o neno e son exhibidas en todos os museos. Paula Sibilia (2015) fai un interesante estudo sobre a evolución da simboloxía do peito e o leite feminino a través da historia, para concluír que a diferencia non está tanto no símbolo como no modo de mirar. Unha mirada que non só varía no tempo, senón tamén difire nas variadas culturas e espazos. En Occidente o peito feminino pasou de ser un receptáculo meramente alimenticio, dentro dunha concepción mística, a ser entendido unicamente como órgano sexual.

\footnotetext{
$6 \quad$ As normas de Instagram indican: "Publicar fotos y vídeos que resulten apropiados para un público diverso. Somos conscientes de que es posible que algunas personas quieran compartir imágenes de desnudos de carácter artístico o creativo; sin embargo, por diversos motivos, no permitimos que se publiquen desnudos en Instagram. Esta restricción se aplica a fotos, vídeos y determinado contenido digital que muestren actos sexuales, genitales y primeros planos de nalgas totalmente al descubierto. También se aplica a algunas fotos de pezones femeninos; sin embargo, sí se permiten fotos de cicatrices de mastectomías y de lactancia materna. También se aceptan desnudos en fotos de cuadros y esculturas". Instagram (2018). Normas comunitarias: https://help.instagram.com/477434105621119 [15.04.2021], https://www.facebook.com/communitystandards/adult_nudity_sexual_activity [15.04.2021].
} 


\section{UNHA ACCIÓN PERFORMATIVA: ESTÍBALIZ ESPINOSA LACTANTE}

[...] Ao outro lado do lenzo, nós. / Aleito cada leito e ínzome de graxa / serei un sil, serei un eume / euquémesei / mater nostra / beta-galactopiranosa + betaglucopiranosa / unha masa de auga administrada por Plinio o Vello / máis / un pouco de zucre por aquí / matrioshka de moloko por alá / e a bágoa de Borenia, a ondina, na cinsa do costro [...].

(Espinosa 2018, publicado previamente en 2007, no seu blog)
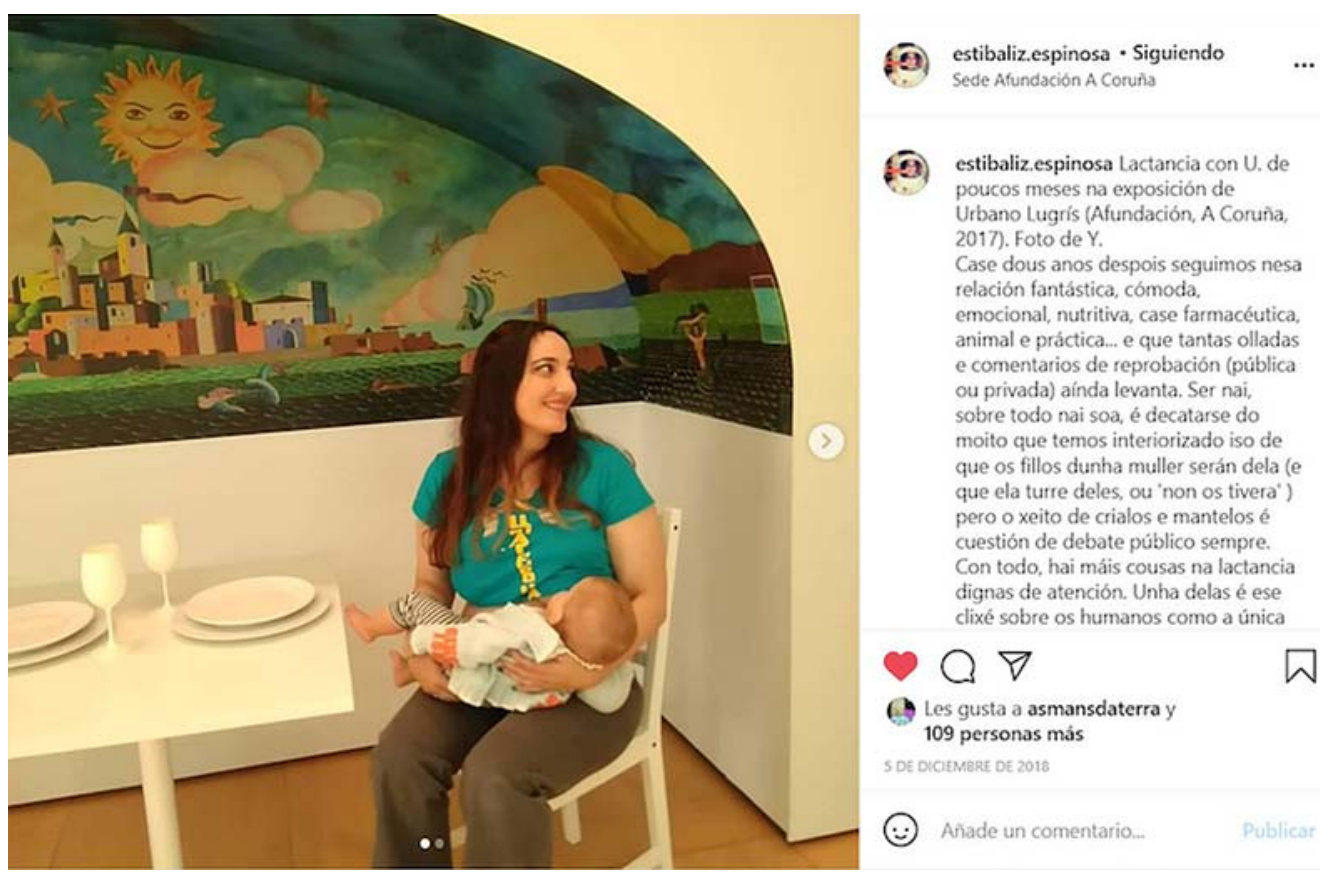

Fig. 5 Publicación de Estíbaliz Espinosa en Instagram (5 de decembro de 2018).

O 5 de decembro de 2018, Estíbaliz Espinosa publica nos seus perfís de Instagram e Facebook dúas imaxes nas que aleita o seu fillo nun espazo público, unha das salas de Afundación (A Coruña). A imaxe foi tomada por y. No é a primeira vez que a autora publica unha fotografía súa nesta situación. No ano 2007, tres anos antes de que fora lanzada a plataforma Instagram, publicaba no seu blog outra imaxe súa aleitando o seu primeiro fillo nas Médulas (León). Esta fotografía inspiraría un poema que hoxe fai parte do seu libro de poemas ...as neuronas irmás... (2018). 


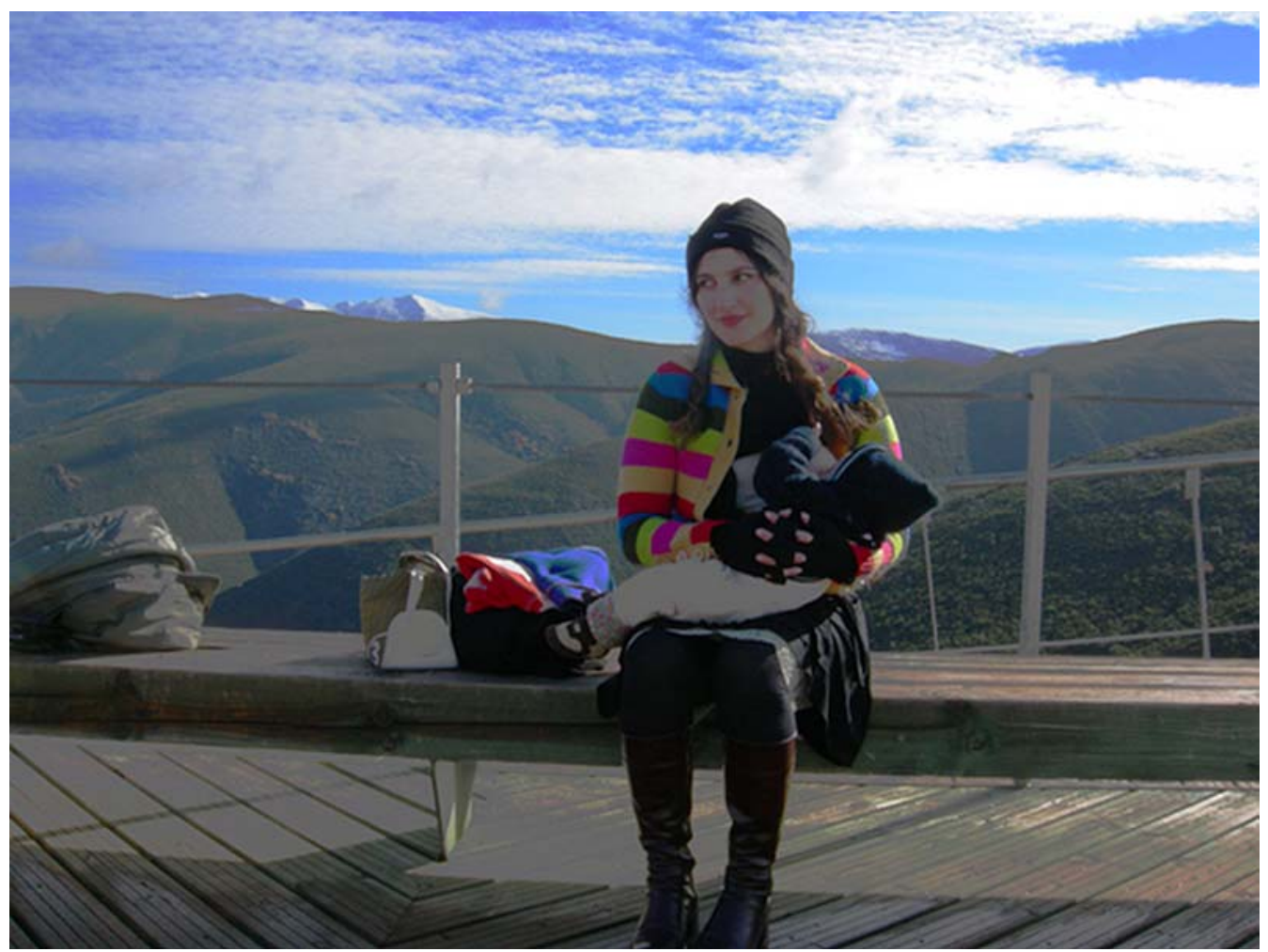

Fig. 6 EE aleitando o seu fillo nas Médulas. Imaxe tirada do seu $b \log ^{7}$. Fotografía de Irving Brea (2007).

Nas imaxes publicadas en Instagram en decembro de 2018, EE posa diante da cámara, cunha obra do artista Urbano Lugrís ${ }^{8}$ no fondo. A un lado ten una mesa disposta para dúas persoas. A súa ollada non está no cadro, nin no neno, fuxe da intimidade do privado para irromper no público, procúranos e desafíanos. $\mathrm{Na}$ imaxe da dereita sorrí, procura a ollada cómplice da audiencia. As dúas imaxes semellan unha galaktotrophousa $a^{9}$, que, nesta ocasión, de-constrúe a comunicación maternal para provocar unha reacción na audiencia e enfrontar o rexeitamento social; igualmente, para ser ela propia peza escultórica de museo.

Retratarse nun museo, ante unha obra de arte, ben realizando un selfie ou cunha fotografía realizada por outra persoa introduce unha nova dimensión do que consideramos performance, trátase de realizar unha nova acción no espazo, unha irrupción na escena previamente creada pola persoa que realizou a obra inicial. Analizaremos a seguir esa composición previa da representación obxecto do noso estudo, como un diorama ou maqueta da creación.

\footnotetext{
7 https://estibalizespinosa.com/2007/o2/16/aleito/ [15.04.2021].

8 Urbano Lugrís (1908-1973) foi un artista e escritor galego, fundador e director da revista Atlántida. A súa obra plástica móvese entre o surrealismo e a plástica metafísica de Chirico. Os temas da mitoloxía celta, o mundo onírico e o mar son fontes recorrentes na súa obra. Destacou como muralista, especialmente en espazos públicos de restauración.
}

9 Galaktotrophousa é o nome que reciben as iconas bizantinas que representan a virxe aleitando o neno. 

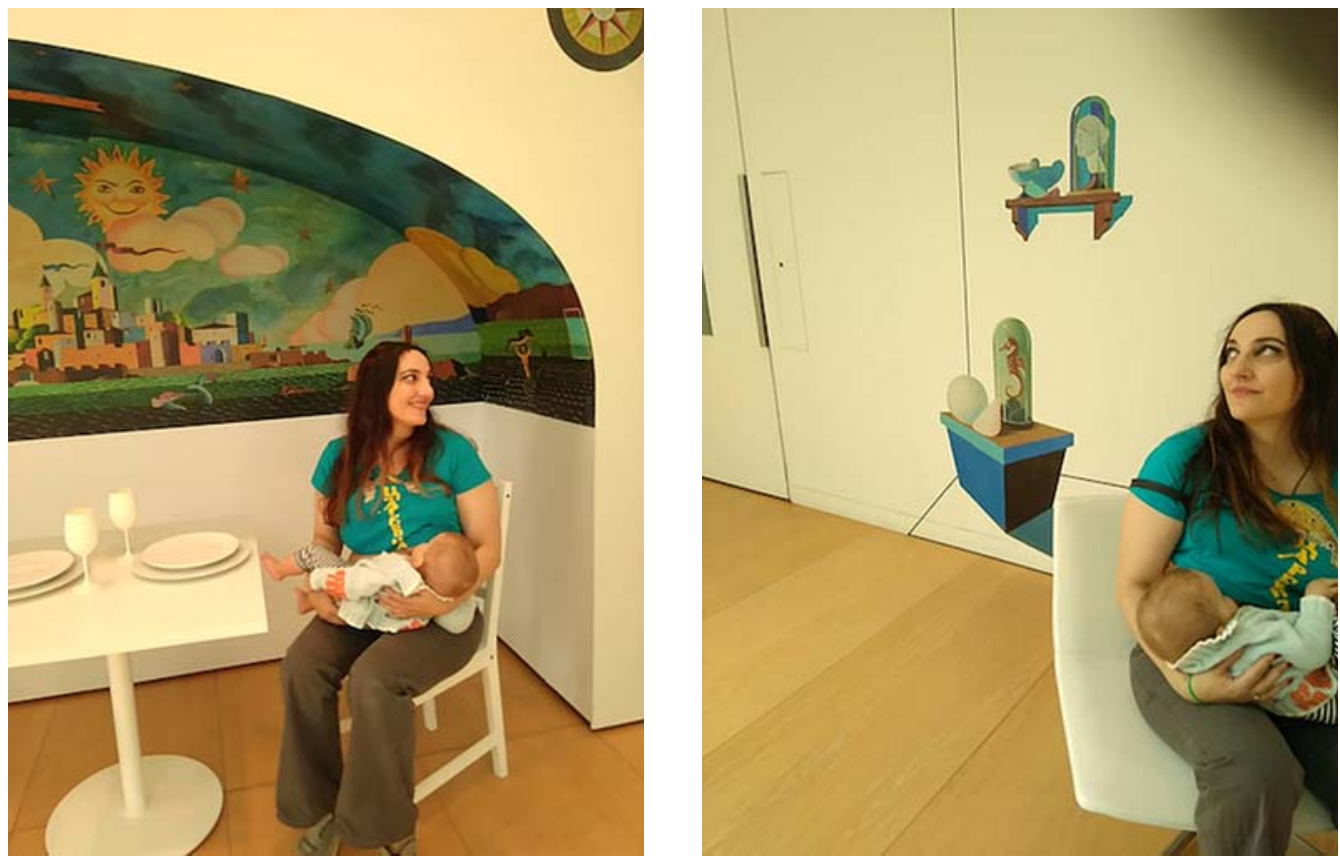

Figs. 7a e $7 \mathbf{b}$ As dúas imaxes de Estíbaliz Espinosa extraídas da súa publicación en Facebook (5 de decembro de 2018).

A escenografía está composta, en primeiro lugar, por unha mesa con dúas cadeiras, pratos e copas para dous comensais. Forman parte da montaxe creada polo museo para a exposición da obra de Lugrís. A intención de Afundación é presentar o espazo en que adoitaban estar as pinturas murais do pintor, bares e restaurantes, dos que foron recuperados para poder ser observados nun espazo artístico. Porén, ese atrezzo é utilizado por EE como perversión do público e o privado; represéntase como nai que aleita nunha esfera privada (o fogar -a mesa e cadeiras poderían ser o cuarto da casa), como figura lactante (peza de museo, Madonna galaktotrophousa [Fig. 8], icona ou escultura) nun espazo público e, de novo, como artista que subverte o código social patriarcal, ao aleitar nun museo e no que sería a representación do restaurante (na exhibición do mesmo), dous espazos públicos.

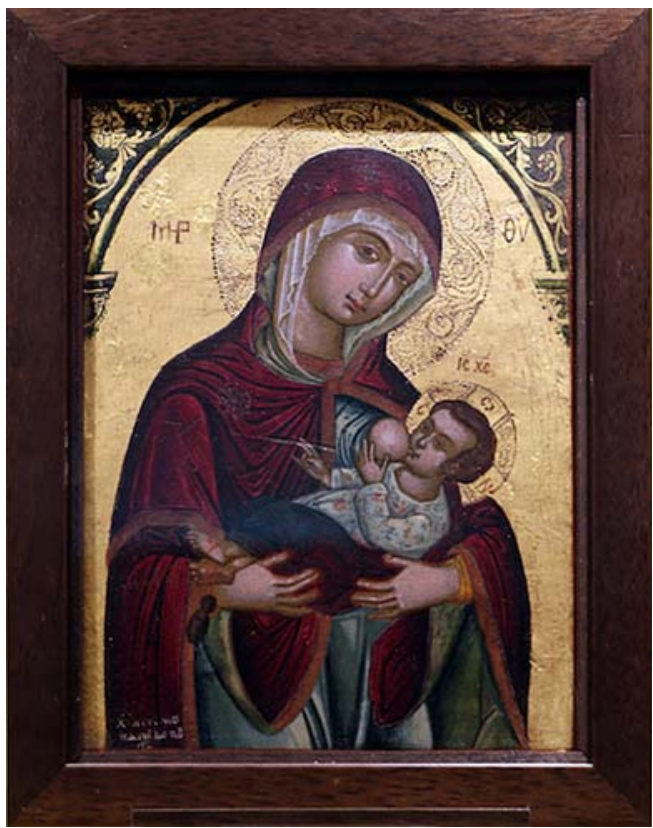

Fig. 8 Antonio Papadopoulos, Madonna galaktotrophousa (ca. 1450-1500). Biblioteca vaticana. 
O segundo elemento é unha pintura mural exposta nun museo. A elección da obra de Urbano Lugrís coa que Espinosa establece o diálogo non é casual. Introduzámonos como público no mural e analicemos a simboloxía das súas imaxes. O mar é o protagonista, algo habitual na obra do pintor, un océano poboado de seres mitolóxicos que se mesturan con aspectos reais: sereas, tritóns e peixes unicornio atravesan a costa galega ante a ollada dos faros, as rochas, o sol e a lúa. A cidade da Coruña (representada pola torre de Hércules) é outro espazo público no que se enmarca a acción de aleitar, unha espectadora múltiple, a cidade cunha ollada permanente, de día e de noite. Nese océano está a serea, imaxe híbrida, símbolo patriarcal de muller que oculta a súa sexualidade ao tempo que se amosa como obxecto sexual ante o home, cos peitos nus.

En oposición, temos a artista da performance, EE que posa ante o cadro e ante a serea. Aquí os peitos aleitan e provocan, por seren vistos como algo privado que se expón nun espazo público. O corpo e os seus fluídos son utilizados como soporte da expresión artística, bodyart, cunha dimensión social. Non é un corpo transgresor na liña de Ron Athey ou Marina Abramović, mais si transgride a norma social.

Axente fundamental é, tamén, a persoa que realiza a fotografía, de quen só nos é ofrecida a inicial $\mathrm{y}$. A intención da autora é manter o seu anonimato na performance das RSD, non identificar á persoa que está tras a cámara. No entanto, na investigación realizada puidemos saber que esa inicial corresponde a Yare B. Espinosa, o seu fillo maior e co-protagonista da imaxe que Ee publicara en Facebook no ano 2007 (Fig. 6). Resulta de interese que a súa ollada actual, desde fóra do cadro, capte a da súa nai dentro dunha performance lactivista que ten como co-protagonista o seu irmán. É co-autor, ao tempo que espectador e pasa de ser suxeito pasivo a activo na intervención.

Finalmente está o público do museo e a audiencia das RSD. EE pasa a formar parte da escena, introduce vida, nun acto co-performativo no que dialoga coa obra de Lugrís, co espazo do museo, con quen tira a fotografía, coas persoas que visitan o museo e a ven aleitar o seu fillo, e con nós, expectantes no ciberespazo. Deixa de ser espectadora para ser executora da acción e ser ela obxecto, obra de arte a ser contemplada nun museo. De feito é esa unha das propiedades que Barthes adxudicaba á fotografía: "La Photographie transformait le sujet en objet, et même, si l'on peut dire, en objet de musée" (1980: 29). A autora (re)preséntase ante outras e outros nunha situación vital: lactación, aleitar o seu fillo nunha escena, nun museo e ao mesmo tempo represéntase mentres é fotografada por Y., para ser despois presentada ante un público que accede a ela dende o artificio (as plataformas sociais en liña). É nese momento, na súa pose, cando é observada, que se constitúe como imaxe (25). A acción expándese desde o instante no que comeza (no museo) até o infinito, na súa reprodución en Facebook ou Instagram, tempo en que se poden producir intervencións do público de rexeitamento ou empatía.

De revisarmos algunhas das imaxes de mulleres lactantes que hoxe están en diferentes museos, observamos unha similitude das fotografías de EE coas obras de Mosnier, Frida Kalho ou as fotografías de Isa Sanz da serie Alma mater. EE busca a mirada externa, aberta, na procura de complicidade ou nunha actitude clara de subversión, da consciencia de poder ser censurada. Onde olla? Ao público do museo? Ao público das redes? Á persoa que tira a fotografía? Á serea de Lugrís? Contraponse a outras imaxes de maternidades en que nai e fillo forman un círculo pechado e íntimo. 


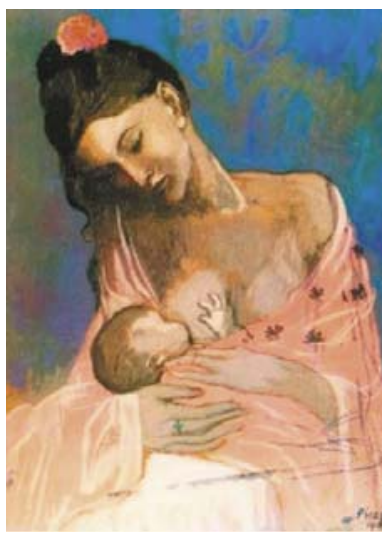

Fig. 9 Pablo Picasso, Nai e fillo (1901-1904).

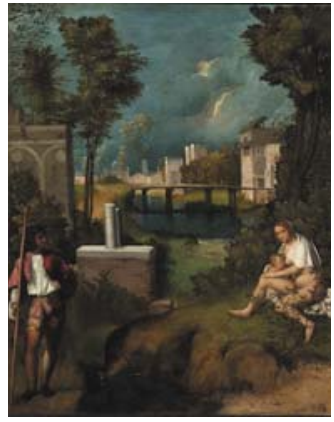

Fig. 12 Giordione, La tempesta (1508).

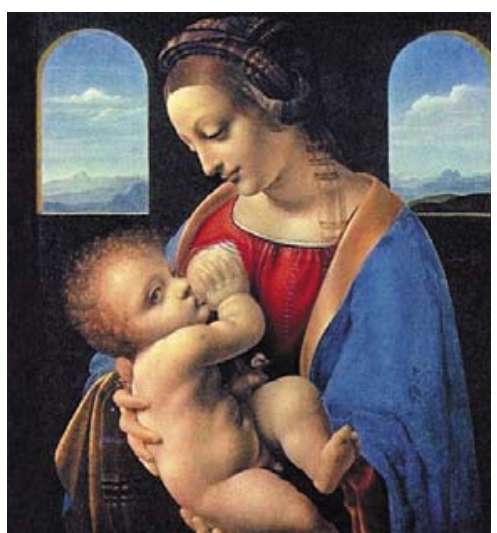

Fig. 10 Leonardo da Vinci, Virxe do leite (1490-1491).

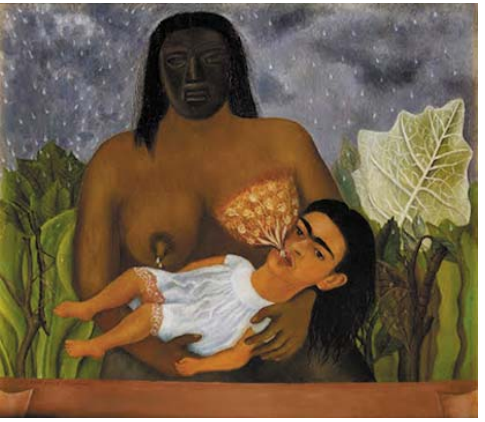

Fig. 13 Frida Kahlo, Mi nana y yo (1937).

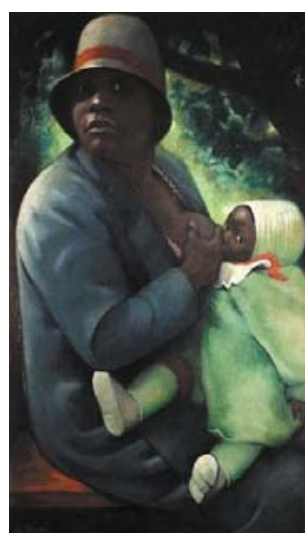

Fig. 11 Ernst Neuschul, Black mother (1927-1931).

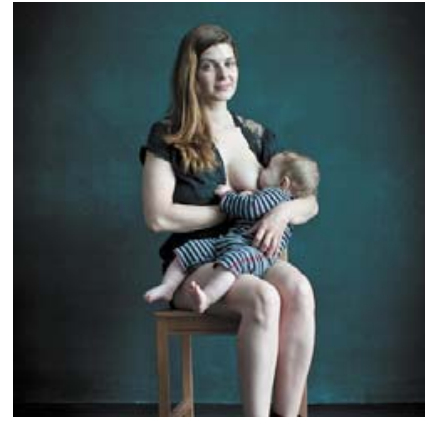

Fig. 14 Isa Sanz, Fotografía da serie Alma mater (2017). Tomada da súa web ${ }^{10}$.

A elección dun museo como lugar de subversión e espazo para a súa performance pode incluírse dentro da resposta de lactivistas que realizan este tipo de accións como protesta contra a expulsión de mulleres que aleitaban o seu fillo nun museo ou galería artística (Museo Picasso de Málaga ou no Museo de Arte Moderno de México). A diferencia é que EE é unha creadora que utiliza diferentes linguaxes artísticas na súa acción (fotografía, performance e poesía).

Neste sentido, de imaxe de muller lactante desafiante e valente na arte, temos outras achegas, como a proposta da cineasta arxentina Anaí Berneri para o cartel do seu filme Alanis. A actriz Sofía Gala Castiglioine posa ante a cámara do artista Luis Sens aleitando o seu propio fillo de dous anos, nunha posición que a censura cualificou de obscena e cunha ollada que foi considerada sexual e non maternal, o cal deu lugar á prohibición da proxección do filme nalgunhas salas. No entanto, apunta Sibilia (2015), a cuestión

10 https://www.isasanz.com/english/art-work/alma-mater/ [15.04.2021]. 


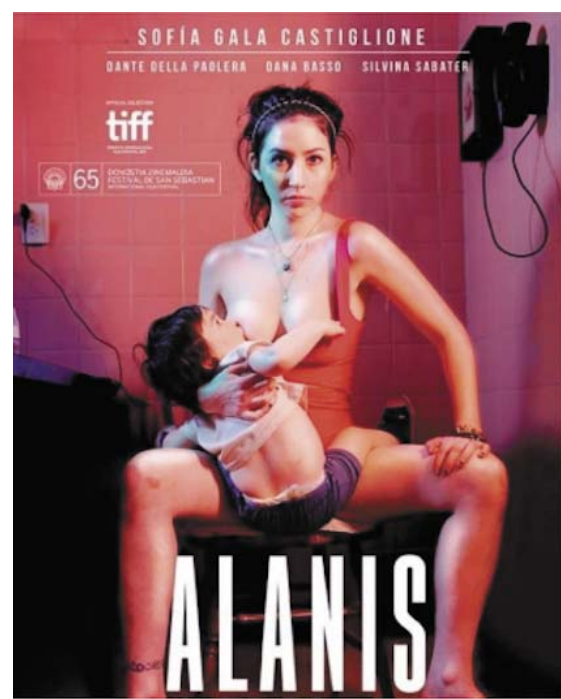

Fig. 15 Cartel do filme Alanis (2017).

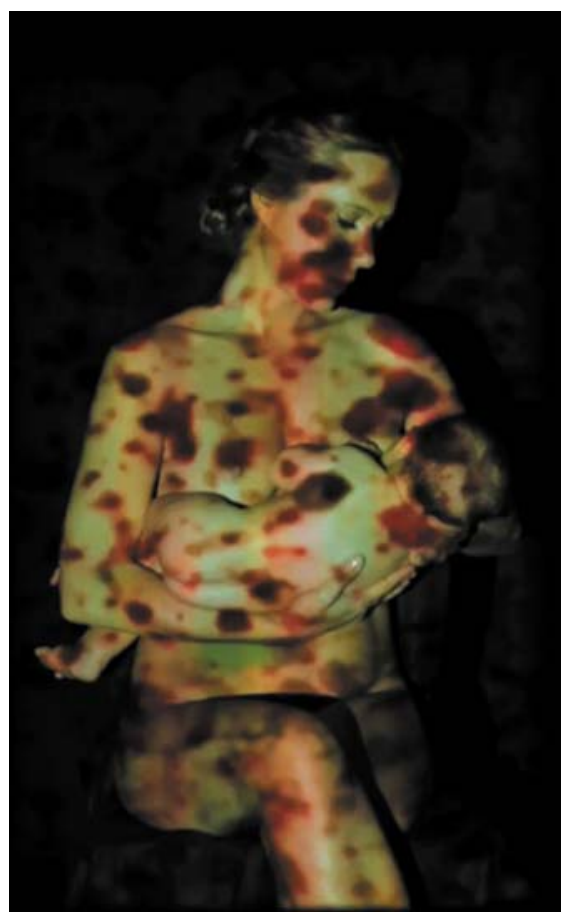

Fig. 16 Fotograma de Vía láctea (2013) de Xisela Franco. está no modo de mirar da sociedade, unha construción social, histórica e variable, que a partir de 1750 optou por "erotizar" o peito feminino.

Poderiamos ofrecer outros exemplos visuais e performativos más próximos á autora, como Vía láctea (2013), de Xisela Franco, curta de catro minutos onde a propia creadora se autoretrata, coma unha Madonna, durante o proceso de aleitamento e, sobre os corpos nus de nai e filla, proxecta un filme antigo de $16 \mathrm{~mm}$, intervido coa intención de crear un efecto de manchas abstractas. O son semella un corazón que bombea sangue e pingas de líquido que se derraman para concluír na resonancia gutural do bebé satisfeito. O vídeo foi proxectado sobre un lenzo con moldura na Exposición "Memoria desde a ruína" no Auditorio de Cangas en 2014.

Debemos contextualizar estas accións dentro do que se vén en denominar maternidades subversivas ${ }^{11}$, aquelas onde a muller transgride a orde simbólica establecida en relación ao seu corpo e á capacidade de xerar vida, un corpo que, no sistema patriarcal, é construído como obxecto de pracer e procreación; propostas que se postulan por unha resignificación da maternidade. Neste senso é pertinente referir outros exemplos galegos nas diferentes expresións artísticas onde se inclúen tanto propostas lactivistas como outras relacionadas coa violencia obstrética ou outros aspectos da maternidade. Salientamos así, nas artes escénicas Anatomía dunha serea (2018), peza documental arredor da violencia á que é sometida a muller no parto, interpretada por Iria Pinheiro a partir dun guión escrito por ela mesma e María Lado. No eido literario María Comesaña Besteiros (2015) trazou unha clasificación denominando as variadas posicións como fillocéntrica, negada, práctica, telúrica e queer. No primeiro caso teríamos a Xela Arias ou María Lado,

11 A escritora e artista multidisciplinar María Llopis, no libro Maternidades subversivas (2015), inclúe numerosos exemplos de modelos de maternidade que creban os prexuízos morais e patriarcais, como maternidades queer, pro-sex, partos orgásmicos, matriactivismo e lactivismo. 
con propostas poéticas onde o fillo adquire todo o protagonismo. No polo oposto estaría Emma Pedreira e a maternidade negada ou escrava, entendida como submisión ás normas patriarcais e, por tanto, continuación do dominio masculino: "Xa non seremos paridoras de matrias nin proporción láctea, / xustificación e deriva das palabras arremetendo bágoas pola boca adentro" (2001: 11). O paradigma de maternidade práctica, a da igualdade, sería a que transmite Inma López Silva en Maternosofía (2014). Unha maternidade telúrica e simbólica está presente nos textos de Lupe Gómez, Chus Pato ou Olga Novo. Neste último caso poderiamos referir o poemario Feliz Idade, onde unha nai telúrica nutre e acalma o "instinto de succión / coma quen apreixa os beizos contra o ar para extraer a luz do día" (Novo 2019: 42). Finaliza Comesaña co que ela designa como maternidade queer, onde se exclúe a función do patriarca e onde cita a EE e o seu poemario Zoommm. Textos biónicos (2007). Con respecto a esta última cuestión concordamos na aplicación dunha lectura queer á gran parte da obra da poeta que analizamos, ela mesma se identifica como unha criatura híbrida, ser artificial ou cyborg e reivindícase como nai soa por elección, fóra de estruturas hetero-centralistas e patriarcais.

Que é o que fai que as imaxes de EE, as de Alanis, Xisela Franco, Isa Sanz, Ashlee Wells Jackson ou as de Stacie Turner sexan subversivas? Barthes ofrece, de novo, a clave, son imaxes "pensativas", fannos reflexionar (1980: 65). A fotografía de EE colgada nas redes sociais, se seguimos a Hunter (2018), diríamos que aumenta o número de espectadores e espectadoras do museo Afundación e, asemade, do cadro de Lugrís, xa que será visto, a través da súa performance por multitude de olladas. O corpo de EE e o seu fillo introducen vida no museo e crean unha tensión procurada pola poeta e artista. O mesmo autor cita a Susan Sontag cando di que a fotografía se apropia do obxecto fotografado, neste caso a apropiación é múltiple: $\mathrm{EE}$, quen fai a fotografía (Y.) e nós, que a interpretamos e comentamos nas redes. No entanto, cal é o obxecto da nosa observación? A audiencia interacciona coa obra de arte final, a fotografía que reproduce é unha performance en que se introduce un feito transgresor e onde aparece, ao mesmo tempo, outra obra de arte, ofrecida a través da ollada dunha espectadora e co-creadora que se fai representar como obxecto artístico. O espazo, a persoa que actúa e o público confúndense nunha acción posteatral.

Tomando como punto de partida a hermenéutica de Jauss (1986), baseada na obra de Gadamer, o epicentro da interpretación dunha obra de arte estaría baseada na recepción por parte do público: un público inicial e todas aquelas persoas que contemplarán esa obra ao longo da historia. Esa contemplación é parte da experiencia estética da que tamén participa a figura do artista, como autor ou autora da experiencia creadora. O epicentro desa experiencia é o goce estético (Genuss). Jauss establece tres formas de chegarmos a esa "conducta esteticamente pracenteira" (goce): a consciencia produtiva ou poiesis, a consciencia receptiva (percepción) ou aisthesis (experiencias subxectivas as dúas) e a experiencia inter-subxectiva, de involucración e re-equilibrio emocional ou catharsis (1982: 76-77).

A horizontalidade dos tres estados da comunicación de Jauss dá lugar a unha complexa engranaxe circular nas obras interdisciplinares e transmedia, como é no caso da obra de Espinosa que analizamos. A autora é creadora e receptora; accede á poiesis desde a aiesthesis da visión do mural de Urbano Lugrís, e desde a catharsis da identificación e subversión da experiencia contemplativa. De novo, pasa a ser receptora da súa obra 
final exposta nas RSD. Igualmente, o público non só experimenta o goce estético da contemplación, senón que chega a dialogar coa obra final, involúcrase, expresa a súa opinión nas RSD, participa e co-crea. A persoa que realiza a fotografía, mencionada como Y., por $\mathrm{EE}$, é, simultaneamente, espectadora e co-creadora, como indicamos con anterioridade, xa que a súa fotografía da performance realizada no museo, é a que vai estar colgada nas RSD acompañada do texto da autora.

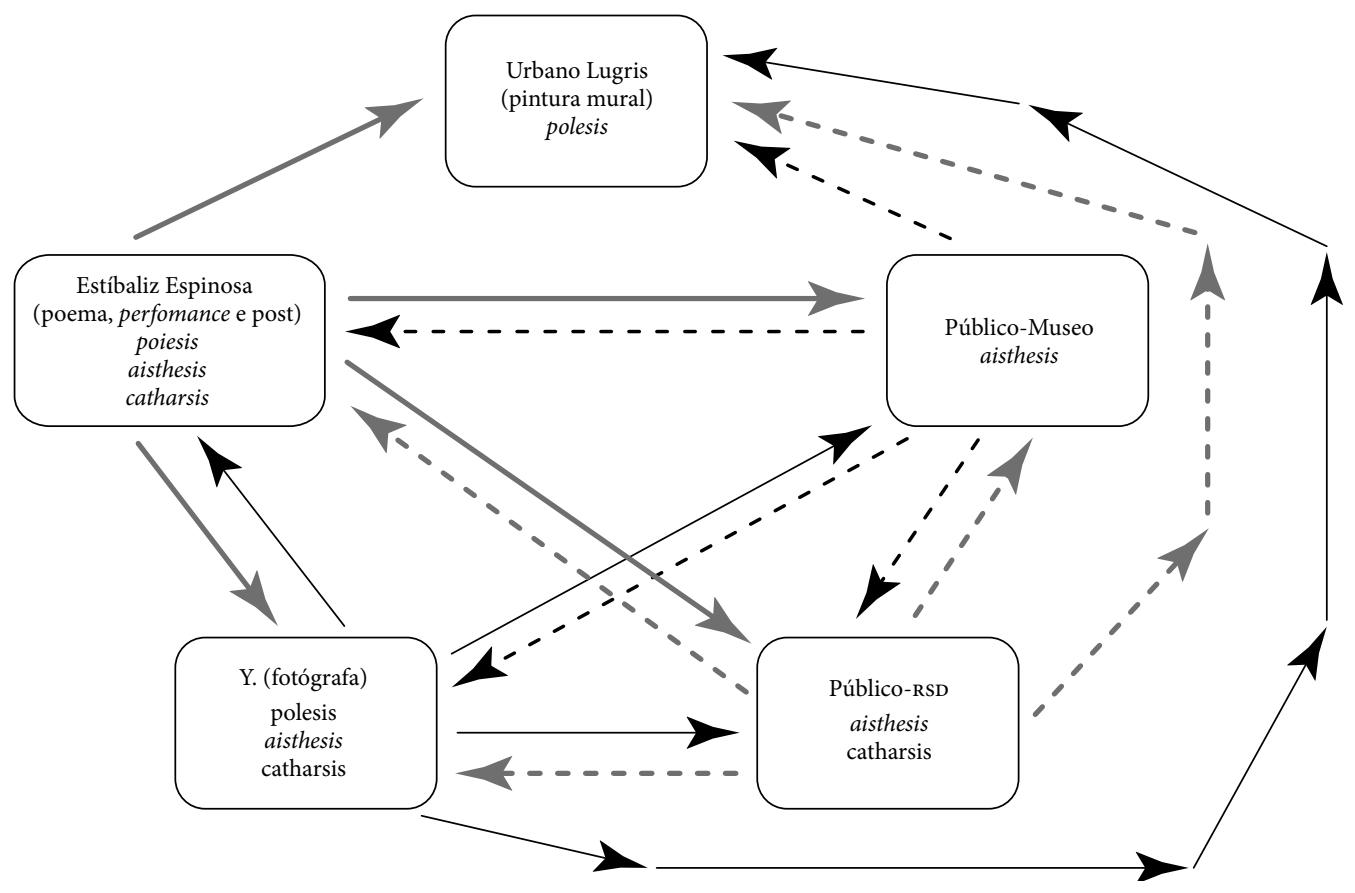

Fig. 17 Aplicación de hermenéutica de Jauss á obra de Estíbaliz Espinosa.

Se afondamos na obra de Gustavo Pernas Cora, Os ollos de Victorine (2006), podemos observar esa ollada de Victorine en EE, reclamando a resposta e intervención do público, a apertura da súa mirada e, a un tempo, a "miraxe oblicua" (Cornago 2005). De confrontarmos o cadro de Manet (Fig. 18) e a escena performativa de EE (Figs. 2, 7a e 7b) extraemos unha serie de converxencias. Non afondaremos no estudo da obra do pintor francés, porén, si retomaremos algúns dos aspectos presentados no libro Pernas Cora.

En Le déjeuner sur l'herbe preséntanse catro figuras, dúas femininas e dúas masculinas. A personaxe feminina espida é a que atrae a mirada do auditorio, non polo feito da súa nudez senón por formar parte dun espazo onde non lle sería propio aparecer sen roupa, un almorzo campestre, onde tanto a muller que se inclina sobre o río como os homes que a acompañan están vestidos. No entanto, a provocación do cadro vén, especialmente, por dúas cuestións: o realismo que está presente nesa figura que semella a de calquera muller coetánea que puidera ter sido fotografada, talvez, despois de saír do baño; e por presentar unha ollada desafiante, sabedora de estar no foco de mira de quen a está a observar. A quen miraba Victorine Meurent? Preséntase nunha pose procurada e ensaiada que, dal- 


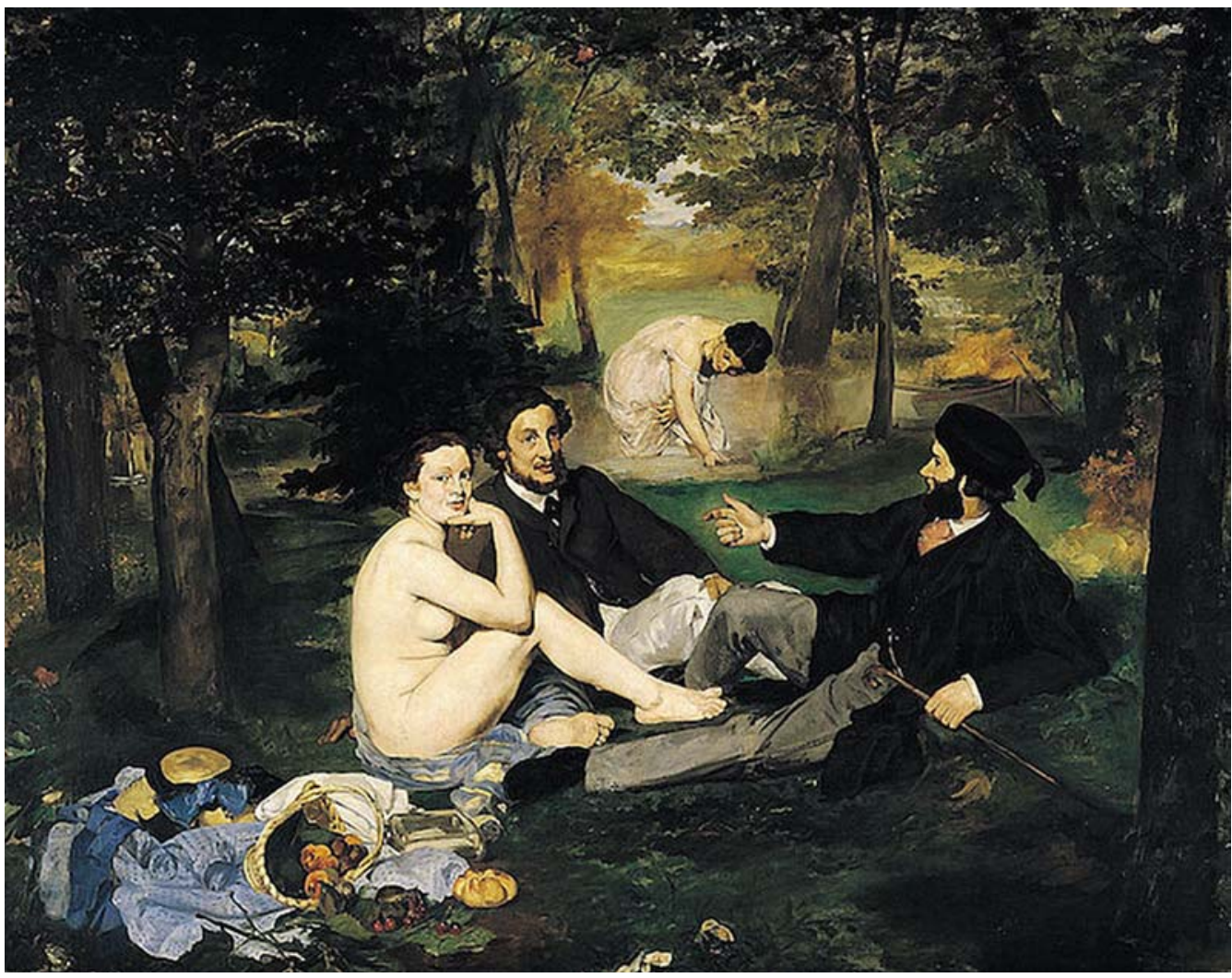

Fig. 18 Édouard Manet, Le déjeuner sur l’herbe (1863).

gún xeito, reta a sociedade burguesa do momento. Esa mesma ollada xa estaba presente no óleo de Giorgione La tempesta (Fig. 12), na muller que aleita o seu fillo e volve a cabeza cara nós. A quen desafía Victorine? Acaso a algún voyeur fóra do cadro? O público podería estar representado no lenzo, como indica Pernas Coira, nas dúas figuras masculinas enfundadas nunha vestimenta negra, típica do momento e que produce un forte contraste coa brancura do corpo nu da protagonista.

Victorine e EE convídannos a entrar na escena, provocando, en ambos escenarios, a ruptura da cuarta parede. "A preceptiva de Diderot sobre a parede invisible é experimentada por Manet no Déjeneur dun xeito provocador, e, a diferenza dos intentos precedentes, aquí a mirada frontal e desafiante de Victorine adquire signos de subversión" (Pernas Cora 2006: 76). Os dous exemplos comparados desatan unha mirada múltiple e oblicua, a das persoas que observan desde olladas heteroxéneas e diversas (temporais e socio-culturais).

A performance da autora galega ten lugar, como xa comentamos, nunha esfera pública, unha sala de exposicións, como tamén era o espazo museístico o destino do cadro de Manet, primeiro o Salón da exposición Universal de 1863 e actualmente no Musée d'Orsay, en París. A poeta galega racha coa imaxe da muller no privado e convirte aquilo que a sociedade considera un acto íntimo nunha acción pública e política, 
"o persoal é político", retomando o lema da segunda ola do feminismo e ampliado por Ester Massó Guijarro a "todo lo sexual es político" (2013:520). A mirada do público é a mirada da sociedade, que en ocasións é de reprobación, como a mesma $\mathrm{EE}$ indica no texto que acompaña á imaxe (Fig. 5):

Case dous anos despois seguimos nesa relación fantástica, cómoda, emocional, nutritiva, case farmacéutica, animal e práctica... e que tantas olladas e comentarios de reprobación (pública ou privada) aínda levanta. E referíndose aos fillos de nai soa "[...] o xeito de crialos e mantelos é cuestión de debate público sempre". Polo que ten que ver coa lactancia materna engade que é esgrimido como unha especie de aberración cultural. (2018)

Instagram é unha rede social na que, se o noso perfil é privado, só se compartirán as imaxes con aquelas persoas que nós aceptemos como espectadoras, é por tanto, o que se considera unha rede semi-pública. O debate entre o público e o privado das redes sociais serve a EE e a outras mulleres, moitas delas celebridades, para entrar no debate da lactación materna como unha acción a desenvolver nos espazos públicos. Neste caso a autora está nun espazo público, mais podería estar nun espazo privado ou doméstico como simula a mesa posta para dúas persoas, íntima, que salta ao espazo público por estar colgado na rede.

\section{CONCLUSIÓNS}

Concluímos que a performance desenvolta por EE no museo Afundación é unha acción posdramática, unha (re)presentación que fuxe da centralidade do texto e que ten o corpo e a audiencia (a mirada do outro) como protagonista; igualmente estamos ante unha proposta transmedia, que combina na súa produción varios elementos: fotografía, pintura, medios dixitais e texto. O texto, non sendo o protagonista, está presente na obra final, no post de Facebook e Instagram; a imaxe tamén dialoga cun poema publicado no libro ...as neuronas irmáns... (2018). A obra, de forte contido artístico, convértese nunha proposta paradigmática de net.art ciberfeminista e unha acción lactivista, transgresora do discurso patriarcal con respecto á maternidade que ten como marco e espazo de enunciación e resistencia, as redes sociais dixitais. Dentro desta cuestión é determinante como o suxeito artístico se transforma en suxeito político capaz de crebar as normas e estruturas hexemónicas e, por tanto, de modificar o sistema social.

Esta intervención é parte dun mapa de maternidades subversivas que se estende no mundo occidental e que ten en Galicia unha ampla resposta nas diferentes expresións artísticas, tanto no eido do visual e performativo como no literario. A acción individual inclúese así nunha acción colectiva, en sororidade, dentro dun pacto de xénero e unha fronte común diversa.

O enigma da mirada de Estíbaliz Espinosa superponse ao enigma que provoca toda a composición visual, requirindo, da audiencia, esa apertura da ollada que reclamaba 
Gustavo Pernas Coira (2006) para a lectura do cadro de Édouard Manet Le déjeuner sur l'herbe. E esa ollada é múltiple, como o é a diversidade do público. Neste senso, é pertinente cuestionar se a resposta de quen observa tras a cuarta parede pode chegar a ser, nalgún aspecto, unívoca, ou se esa transgresión ou subversión provoca tantas respostas como suxeitos se moven no ciberespazo. No prólogo de L'ombilic des limbes, Antonin Artaud expresa non concebir a obra na marxe do espíritu: "Il faut en finir avec l'Esprit comme avec la littérature. Je dis que l'Esprit et la vie communiquent à tous les degrés” (1925: 4). Así, para Espinosa, a obra é vida e a vida é obra, espírito, vida e obra comunícanse, dialogan ante unha audiencia plural e diversa.

Finalmente, procede salientar como este tipo de accións lactivistas inclúen unha pose que non é allea a unha iconografía heteronormativa e cisxénero exhibida en todos os museos; referímonos, fundamentalmente, ás representacións de madonnas. No entanto, a intención é, precisamente, de-construír o discurso inicial, liberar o corpo da muller da posición subalterna outorgada ao longo da historia da arte e da humanidade, crebar a dicotomía entre peito lactante e peito erotizado e crear novos modelos de maternidades, elaborados desde e para os nosos corpos.

\section{BIBLIOGRAFÍA}

Abuín GonzÁlez, Antonio (2006) Escenarios del caos. Entre la hipertextualidad y la performance en la era electrónica. Valencia, Tirant lo Blanch.

Arendt, Hanna (2001 [1958]) A condição humana. Trad. Roberto Raposo. Lisboa, Relógio d’Água.

Artaud, Antonin (1925) Lombilic des limbes. Paris, Editions de La Nouvelle Revue Française.

Artaud, Antonin (1938) Le théâtre et son double. Paris, Gallimard.

AugÉ, Marc (1992) Non-Lieux, introduction à une anthropologie de la surmodernité. Paris, Seuil.

Barthes, Roland (1972) Critical Essays. Evanston, Northwestern University Press.

Barthes, Roland (1980) La chambre claire. Note sur la photographie. Paris, Seuil.

BhabHa, Homi K. (1994) The location of culture. London, Routledge.

Bourdieu, Pierre, dir. (1965) Un art moyen. Essai sur les usages sociaux de la photographie. Paris, Ed. de Minuit.

Braidotti, Rosi (2004) Feminismo, diferencia sexual y subjetividad nómade. Barcelona, Gedisa.

Buller, Rachel Epp (2016) "Performing the Breastfeeding Body: Lactivism and Art Interventions". Studies in the Maternal. 8: 14. DoI:10.16995/sim.225.

ButLER, Judith (2007) Gender trouble: feminism and the subversion of identity. New York, Routledge.

Comesaña Besteiros, María (2015) De Dario a Sofía (1996-2014): a representación da maternidade nas autoras. Universidade de Vigo. Tese de doutoramento. http:// hdl.handle.net/11093/838 [15.04.2021]. 
Cornago, Óscar (2005) “QQué es la teatralidad? Paradigmas estéticos de la Modernidad”. Telón de fondo. Revista de Teoría y Crítica Teatral. 1: 1-13.

Debord, Guy (1967) La Société du spectacle. Paris, Buchet-Chastel.

Espinosa, Estíbaliz (2007) Zoommm. Textos biónicos. A Regueifa. http://estibalizespinosa. com/poemas/7448-2/ [8.04.2021].

EsPINosa, Estíbaliz (2018) ...as neuronas irmás... Santiago de Compostela, Centro PEN Galicia.

FernáNDEZ NAVAZAS, Juan (2011) "A lectura performativa e a performance da personalidade en Facebook". Boletín Galego de Literatura. 46: 133-148.

Fontcuberta, Joan (2016) La furia de las imágenes. Notas sobre la postfotografía. Barcelona, Galaxia Gutenberg.

Franco, Xisela (2013) Vía láceta. https://vimeo.com/111527983 [8.04.2021].

GILL, Rosalind (2016) "Post-postfeminism? New feminist visibilities in postfeminist times”. Feminist Media Studies. 16: 610-630. DoI:10.1080/14680777.2016.1193293.

Goffman, Erving (1959) The Presentation of Self in Everyday Life. Edinburgh, University of Edinburgh Social Sciences Research Centre.

HUNTER, Elizabeth Brazley (2018) "In the frame: the performative spectatorship of museum selfies". Text and Performance Quarterly. 38: 55-74. DoI:10.1080/10462937.2018.1456673.

IAB SPAIN (2020) "Estudio anual redes sociales 2019". https://iabspain.es/estudio/estudioredes-sociales-2020/ [8.04.2021].

JACKsON, Ashlee Wells (2015) The 4th trimester project: Celebrating the uncensored beauty of motherhood. Tempe (Ст), SparkPress.

Jauss, Hans Robert (1986) Experiencia estética y hermenéutica literaria. Madrid, Taurus.

LACAN, Jacques e Miller, Jacques-Allain (2006 [1968-1969]) Le Séminaire Livre XVI.

D’une Autre à l'autre. Paris, Seuil.

LAGARDE, Marcela (2009) "La política feminista de la sororidad". Mujeres en Red, el periódico feminista. 11. http://www.mujeresenred.net/spip.php?article1771 [8.04.2021].

Lehmann, Hans-Thies (1999) Postdramatisches Theater. Frankfurt am Main, Verlag der Autoren.

Llopis, María (2015) Maternidades subversivas. Tafalla, Txapalata.

LóPez SiLva, Inma (2014) Maternosofía. Vigo, Galaxia.

Massó Guijarro, Ester (2013) "Deseo lactante. Sexualidad y política en el lactivismo contemporáneo". Revista de Antropología Experimental. 13: 515-529.

MAssó Guijarro, Ester (2015a) “Lactivismo”. En: María Llopis Maternidades subversivas. Tafalla, Txalaparta: 183-191.

Massó Guijarro, Ester (2015b) "Lactivismo contemporáneo en España: ¿una nueva marea sociopolítica?” Journal of Spanish Cultural Studies. 16 (2): 193-213. DoI: 10.1080/14636204.2015.1069074 [8.04.2021].

Novo, Olga (2019) Feliz Idade. Pontevedra, Kalandraka.

Pedreira, Emma (2001) Velenarias. A Coruña, Espiral Maior.

PÉRez, Marta e Sotelo, Vanesa (2013) “Tomar as rendas e crear á inversa. Unha perspectiva feminista da creación escénica en Galicia”. RGT. Revista galega de teatro. 73: 7-16.

Pernas Cora, Gustavo (2006) Os ollos de Victorine e a construción da cuarta parede. Ames, Laiovento. 
Pham, Minh-Ha T. (2015) "I Click and Post and Breathe, Waiting for Others to See What I See: On \#FeministSelfies, Outfit Photos, and Networked Vanity”. Fashion Theory. 19: 221-241. DOI:10.2752/175174115X14168357992436.

PiñHeIro, Iria e Lado, María (2018) Anatomía dunha serea. Guión teatral.

RÁbade Villar, María do Cebreiro (2018) “Galician Feminisms post-1996”. En: Silvia Bermúdez e Roberta Johnson (eds.) A New History of Iberian Feminisms. Toronto, University of Toronto Press: 375-383.

Rettberg, Jill Walker (2017) "Self-Representation in Social Media". En: SAGE Handbook of Social Media, cap. 23. https://hdl.handle.net/1956/13073 [8.04.2021].

Schmeichel, Mardi, Kerr, Stacey e Linder, Chris (2017) "Selfies as postfeminist pedagogy: the production of traditional femininity in the us South". Gender and Education. 6: 1-19. DOI:10.1080/09540253.2017.1411890.

Schwartz, Raz e Halegoua, Germaine R. (2015) "The spatial self: Location-based identity performance on social media". New Media \& Society. 17: 1643-1660. DOI:10.1177/1461444814531364.

Sibilia, Paula (2008) La intimidad como espectáculo. México, Fondo de Cultura Económica.

SibILIA, Paula (2015) "La 'pornificación' de la mirada: una genealogía del pecho desnudado". Cuadernos de Música, Artes Visuales y Artes Escénicas. 10: 35-63. DoI:10.11144/ Javeriana.mavae10-1.pmgp.

Turner, Stacie (2013) "Breastfeeding in Real Life". Huffington Post. https://www.huffingtonpost.es/2013/10/15/lactancia-materna-fotos_n_4099593.html [8.04.2021].

Villegas, Juan (1999) "Conferencia dictada por Juan Villegas". Teatro. 6: 23-29.

ZAFRA, Remedios (2010) Un cuarto propio conectado: (ciber)espacio y (auto)gestión del yo. Madrid, Fórcola. 